\title{
KORELASI ANTARA HASTA BRATA (KONSEP KEPEMIMPINAN DALAM PERSPEKTIF BUDAYA JAWA) DAN ISLAMIC LEADERSHIP (KONSEP KEPEMIMPINAN DALAM PERSPEKTIF ISLAM)
}

\section{Muhammad Hamim}

Fakultas Humaniora UIN Maulana Malik Ibrahim Malang

Jalan Gajayana 50 Malang. Email: hamim_prof@yahoo.com

\begin{abstract}
Leadership is a process when one directs, guides, affects or control the thoughts, feelings, or behavior of others. It is obvious that leadership is one's action or performance that causes someone else or a group moves toward specific purposes. There are three things that need to be distinguished, the leader, leadership and leading. The position of "leader" is a role in a particular system. Those in a formal role do not necessarily have the leadership skills and not necessarily able to lead. Leadership, is basically related to one's skills, expertise, and level of power. Leadership can be owned by people who are not "leaders". Leadership ability affects others in various ways, while leading is the result of the use of one's role. The leadership concept in the perspective of Javanese and Islam is explored in this article.
\end{abstract}

Kepemimpinan meliputi proses seseorang memimpin, membimbing, mempengaruhi atau mengontrol pikiran, perasaan, atau tingkah laku orang lain. Jelaslah bahwa kepemimpinan merupakan tindakan atau perbuatan seseorang yang menyebabkan seseorang atau kelompok lain menjadi bergerak ke arah tujuan-tujuan tertentu. Terdapat tiga hal yang perlu dibedakan yaitu pemimpin, kepemimpinan dan memimpin. Posisi "pemimpin" adalah suatu peran dalam sistem tertentu. Seseorang dalam peran formal belum tentu memiliki keterampilan-keterampilan kepemimpinan dan belum tentu mampu memimpin. Kepemimpinan, pada dasarnya berhubungan dengan keterampilan, kecakapan, tingkat pengaruh yang dimiliki seseorang. Kepemimpinan bisa dimiliki oleh orang-orang yang 
bukan "pemimpin". Kemampuan kepemimpinan mempengaruhi orang lain dengan berbagai cara, sedangkan memimpin merupakan hasil penggunaan peran seseorang. Konsep kepemimpinan dalam perspektif Jawa dan Islam dieksplorasi dalam tulisan ini.

Keywords: Hasta Brata, Islamic leadership

\section{Pendahuluan}

Dalam kehidupan bermasyarakat, kita sudah tidak asing lagi dengan istilah kepemimpinan. Hal tersebut dikarenakan peran diciptakannya manusia oleh Allah SWT yang tidak lain adalah sebagai Khalifatullah Fil Ardl (wakil Allah di muka bumi). Dengan peran tersebut, manusia diharapkan mampu menciptakan perdamaian dan kemakmuran dalam kehidupan di dunia. Akan tetapi, akhir-akhir ini tidak sedikit kita jumpai fenomena yang cukup membuat kita miris terkait praktik kepemimpinan di Indonesia. Pemimpin tidak lagi menjadi figur panutan bagi rakyatnya. Hampir setiap hari, berita terkait korupsi, penyalahgunaan jabatan, dan perilaku tidak etis para pemimpin mewarnai media masa, elektronik maupun cetak. Padahal, bangsa Indonesia adalah populasi muslim terbesar di dunia yang semestinya mampu mengamalkan isi kandungan kitab suci al Quran sebagai tuntunan kehidupan, tak terkecuali dalam bidang kepemimpinan. Tidak hanya itu, semestinya pemimpin Indonesia dapat belajar dari model dan konsep kepemimpinan yang ada pada kerajaan-kerajaan terdahulu, yang telah mengalami kejayaan dan diakui oleh dunia terlebih kerajaan di Jawa semisal Majapahit, Pajajaran, Kediri, dan sebagainya. Berdasarkan hal tersebut di atas, maka kiranya perlu dikaji konsep yang telah ditawarkan oleh Islam dan ajaran kepemimpinan yang bersumber pada kearifan nusantara, dalam upaya menyambut Indonesia yang makmur dan damai, serta terjadi hubungan yang harmonis antara pemimpin dan rakyat.

\section{Hakikat Kepemimpinan}

Leadership is capability of persuading others to work together undertheir direction as a team to accomplish certain designated objective atau kepemimpinan adalah kemampuan meyakinkan orang lain supaya bekerja sama di bawah pimpinannya sebagai suatu tim untuk mencapai atau melakukan suatu tujuan tertentu (Rivai, 2009: 106).

Kepemimpinan adalah suatu proses ketika seseorang memimpin 
(directs), membimbing (guides), mempengaruhi (influences) atau mengontrol (controls) pikiran, perasaan, atau tingkah laku orang lain. Dapat dipahami di sini, bahwa kepemimpinan merupakan tindakan atau perbuatan seseorang yang menyebabkan seseorang atau kelompok lain menjadi bergerak ke arah tujuan-tujuan tertentu (Pahlawan, 2005: 7). Terdapat tiga hal yang perlu dibedakan berkaitan kata dasar pimpin, yaitu pemimpin, kepemimpinan dan memimpin. Posisi "pemimpin" adalah suatu peran dalam sistem tertentu. Seseorang dalam peran formal belum tentu memiliki keterampilan-keterampilan kepemimpinan dan belum tentu mampu memimpin. Kepemimpinan, pada dasarnya berhubungan dengan keterampilan, kecakapan, tingkat pengaruh yang dimiliki seseorang. Kepemimpinan bisa dimiliki oleh orang-orang yang bukan "pemimpin". Kemampuan kepemimpinan mempengaruhi orang lain dengan berbagai cara. Sedangkan memimpin, merupakan hasil penggunaan peran seseorang (Wirjana, 2002: 29-30).

Terdapat dua jenis pemimpin, pemimpin yang baik dan pemimpin yang tidak baik (Rivai, 2009: 122). Pemimpin yang baik akan mengkomunikasikan energinya, antusiasmenya, ambisinya, kesabarannya, kesukaannya, dan arahannya. Terdapat beberapa ciri yang dimiliki pemimpin yang baik, yaitu meliputi kejujuran dan integritas, menggerakkan, memiliki gairah memimpin, percaya diri, intelegensi, dan pengetahuan yang relevan dengan pekerjaan. Sedangkan pemimpin yang tidak baik adalah diktator, penggertak, dan tidak konsisten, merasa terancam oleh opini yang berbeda-beda dan akan dikelilingi oleh orang-orang yang memiliki pandangan serupa, menyembunyikan informasi dan menggunakan kekuasaannya untuk mempengaruhi perubahan, menikmati untuk mengintimidasi staf dan seringkali otokratik, tidak memiliki dimensi tunggal, lebih suka memadamkan konflik dari pada menarik keluar perbedaanperbedaan dan sedikit suka bekerja bila ada kedekatan hubungan.

Sementara terkait karakteristik dan kualitas kepemimpinan yang sukses, menggambarkan bahwa terdapat empat karakter, yaitu: a) karakteristik personal: pemimpin harus jujur, percaya diri, terbuka, sportif, dan memiliki keinginan dan kesediaan untuk memimpin, (b) kepemimpinan situasional: dapat menerapkan dukungan dan dorongan yang tepat sesuai dengan situasi dan tingkat kemampuan bawahan (direktif, dorongan atau juga keduanya), (c) kepemimpinan transaksional: pemimpin memahami dan suka membantu bawahan untuk mencapai tujuannya dan dalam waktu yang sama juga mencapai tujuan organisasi, (d) kepemimpinan transformasional: pemimpin memiliki sesuatu yang bermanfaat dan visi yang menantang yang dikomunikasikan, kemudian 
memotivasi dan memberikan inspirasi pada bawahan (Yunus 2009: 25).

\section{Hasta Brata: Konsep Kepemimpinan Dalam Perspektif Budaya Jawa}

Sebenarnya jauh sebelum muncul teori-teori dan kajian kepemimpinan kontemporer, dalam budaya nusantara khususnya Jawa, sudah dikenal memiliki konsep perilaku kepemimpinan yang disebut Hasta Brata. Hasta artinya delapan dan Brata adalah laku atau tindakan. Jadi Hasta Brata adalah delapan tindakan yang harus dilakukan atau dilaksanakan untuk menjadi pemimpin: raja, sultan, presiden, legislatif, bangsawan, tokoh masyarakat, maupun pemimpin organisasi termasuk di lingkungan pendidikan (Mulyono, 2009: 41). Hasta Brata disimbolkan dengan sifat-sifat mulia dari alam semesta yang patut dijadikan pedoman bagi setiap pemimpin (Haditsutrisno, 2009: 96).

Ajaran Hasta Brata ini berisi tentang kepemimpinan sosial yang memiliki delapan prinsip, yaitu (Purwadi, 2007: 170-171):

1. Laku Hambeging Kisma. Maknanya seorang pemimpin yang selalu berbelas kasih dengan siapa saja. Kisma artinya tanah. Tanah tidak mempedulikan siapa yang menginjaknya, semua dikasihani. Tanah selalu memperlihatkan jasanya. Walaupun dicangkul, diinjak, dipupuk, dibajak, tetapi malah memberi subur dan menumbuhkan tanam-tanaman. Filsafat tanah adalah air tuba dibalas air susu. Keburukan dibalas kebaikan dan keluhuran.

2. Laku Hambeging Tirta. Maknanya seorang pemimpin harus adil seperti air yang selalu rata permukaannya. Keadilan ditegakkan bisa memberi kecerahan ibarat air yang membersihkan kotoran. Air tidak pernah emban oyot emban cindhe 'pilih kasih'.

3. Laku Hambeging Dahana. Maknanya seorang pemimpin harus tegas seperti api yang sedang membakar. Namun pertimbangannya berdasarkan akal sehat yang bisa dipertanggungjawabkan sehingga tidak membawa kerusakan di muka bumi.

4. Laku Hambeging Samirana. Maknanya seorang pemimpin harus berjiwa teliti di mana saja berada. Baik buruk rakyat harus diketahui oleh mata kepala sendiri, tanpa menggantungkan laporan dari bawahan saja. Bawahan cenderung selektif dalam memberi informasi untuk berusaha menyenangkan pemimpin.

5. Laku Hambeging Samodra. Maknanya seorang pemimpin harus mempunyai sifat pemaaf sebagaimana samudra raya yang siap menampung apa saja yang hanyut dari daratan. Jiwa samudra mencerminkan pendukung pluralisme dalam hidup bermasyarakat yang berkarakter majemuk.

6. Laku Hambeging Surya. Maknanya seorang pemimpin harus memberi inspirasi pada bawahannya ibarat matahari yang selalu menyinari bumi 
dan memberi energi pada setiap makhluk.

7. Laku Hambeging Candra. Maknanya seorang pemimpin harus memberi penerangan yang menyejukkan seperti bulan bersinar terang benderang namun tidak panas. Bahkan terang bulan tampak indah sekali. Orang desa menyebutnya purnama sidi.

8. Laku Hambeging Kartika. Maknanya seorang pemimpin harus tetap percaya diri meskipun dalam dirinya ada kekurangan. Ibarat bintang-bintang di angkasa, walaupun ia sangat kecil tapi dengan optimis memancarkan cahayanya, sebagai sumbangan buat kehidupan.

Ajaran astabrata memberikan kesadaran kosmis bahwa dunia dengan segala isinya mengandung pelajaran bagi manusia yang mau merenung dan menelitinya. Norma kepemimpinan Jawa dikenal dengan ungkapan sabda pandita ratu tan kena wola-wali, memiliki arti seorang pemimpin harus konsekuen untuk melaksanakan dan mewujudkan apa yang telah dikatakan. Raja/pemimpin tidak boleh sembarangan dalam bersabda/berbicara di depan umum, dan mengambil kebijakan yang tidak boleh berubah-ubah. Seorang raja/pemimpin akan sampai pada sifat-sifat terpuji dan mulia apabila dia tidak asal bicara dan apa yang telah disabdakan tidak akan dirubah atau dikhianati, karena keputusan pemimpin akan menjadi rujukan para pembantunya (Mulyono, 2009: 61).

Peran kepemimpinan hasta brata sehubungan dengan delapan sifat/ perilaku kepemimpinan yang diajarkan oleh Begawan Kesawasidi/Kresna kepada Raden Arjuna maka sebagai pemimpin harus dapat berperan sebagai (Mulyono 2009: 46-48):

1) Komandan, maksudnya sebagai pemimpin harus mampu memerintahkan anak buahnya. Ia harus bertindak tegas dan berani tampil ke depan.

2) Pelopor, maksudnya sebagai pemimpin harus kreatif penuh inisiatif dan bila perlu tampil ke depan untuk membuka jalan. Hal ini bila mengatasi berbagai masalah, maka sebagai seorang pemimpin harus tampil ke depan.

3) Bapak, maksudnya sebagai pemimpin harus bijaksana dan berlaku adil. Pemimpin sebagai bapak harus dapat bertindak sebagai pengayom anak buahnya, memberi harapan kehidupan yang bahagia dan dapat menjamin kesejahteraan seluruh anak buahnya.

4) Berperan sebagai ibu, maksudnya seorang pemimpin harus dapat menampung 
aspirasi anak buahnya dengan cara mampu memahami perasaan mereka. Ia harus memiliki rasa kasih sayang dan mau menampung serta menerima keluhan anak buahnya, laksana seorang ibu.

5) Guru, maksudnya setiap pemimpin dituntut, agar mampu memberikan pendidikan, pengajaran, bimbingan, dan pelatihan kepada setiap anak buahnya guna kaderisasi dan peningkatan dedikasi dan kinerja mereka. Bila sewaktu-waktu pemimpin tidak ada di tempat ataupun pensiun maka sudah ada pembantunya yang dapat menggantikan posisinya.

6) Pendhita/Ulama, maksudnya seorang pemimpin disamping dirinya taat menjalankan ibadahnya, ia juga harus mampu memberikan tauladan agar semua anak buahnya melaksanakan ibadah masing-masing sesuai dengan agama dan kepercayaan yang dianutnya.

7) Sahabat, maksudnya pemimpin tidak perlu menjaga jarak dengan menjauhkan diri dengan anak buahnya. Pemimpin sebagai sahabat berarti adanya unsur keakraban, saling tenggang rasa, bersedia berdialog dan berdiskusi dalam pemecahan masalah setiap kali terjadi.

8) Satria, maksudnya seorang pemimpin harus melindungi dan mau berkorban demi kebahagiaan anak buahnya. Yang paling mendasar pemimpin berperan sebagai satria ialah ia malu untuk berbuat curang dengan melakukan penyelewengan, korupsi dan menyalahgunakan wewenang dan jabatannya.

\section{Islamic Leadership: Konsep Kepemimpinan Dalam Islam}

Imam dan Khalifah adalah dua istilah yang digunakan al Quran untuk menunjuk "pemimpin”. Kata imam terambil dari kata amma-yaummu, yang berarti menuju, menumpu, dan meneladani. Kata khalifah berakar kata khalafa, yang pada mulanya berarti "di belakang", seringkali juga diartikan "pengganti", karena yang menggantikan selalu berada di belakang, atau datang sesudah yang digantikannya. Imam mempunyai makna yang sama dengan khalifah. Hanya saja kata imam digunakan untuk keteladanan. Karena ia diperoleh dari kata yang mengandung arti depan, berbeda dengan khalifah yang terambil dari kata "belakang".

Al Quran menggunakan kedua istilah ini, untuk menggambarkan ciri seorang pemimpin, sekali di depan menjadi panutan. Ing ngarso sung tulodo. Dan dalam arti lain di belakang untuk mendorong sekaligus mengikuti kehendak dan arah yang dituju oleh yang dipimpinnya, atau tut wuri handayani (Rivai, 2009: 112-113). 
Dalam ajaran Islam, kepemimpinan itu penting mengingat momen dan kesempatan pengembangan kehidupan ini membutuhkan kepemimpinan. Kepemimpinan bagaikan mesin bagi kereta api. Kereta api tidak akan bisa bergerak dan berjalan ke suatu tempat tanpa adanya mesin, dan hanya Islamic leadership yang dapat memberikan penyelesaian problematika umat secara sempurna. Kepemimpinan dalam Islam adalah sebuah kepercayaan dari lingkungan yang akan membuka peluang bagi seorang pemimpin untuk dapat mengekspresikan semangat dan kemampuannya guna mengembangkan organisasi yang dipimpinnya. Karena itu, untuk dapat dipercaya, fokus kepemimpinan dalam Islam harus berada di atas nilai-nilai integritas/moral dan keadilan.

Prinsip Islamic leadership adalah sejumlah prinsip kepemimpinan yang diambil dari intisari ajaran dalam al Quran dan biografi Nabi Muhammad SAW dan para sahabat dalam mengelola pemerintahan dan pembangunan secara baik, dan juga keteladanan akhlak kepemimpinan yang dijadikan petunjuk para pemimpin Islam guna mendapatkan kepercayaan dari lingkungan dalam menyelenggarakan organisasi yang islami secara efektif dan benar (Beekun Lulail Yunus, 2009: 45-46).

Disebutkan dalam buku Lisaanul Arab, kata al qaudu 'memimpin atau menuntun' lawan kata dari 'as sauqu yang berarti 'menggiring', seperti perkataan menuntun binatang dari depan dan menggiring binatang dari belakang (Habiburrahman, 2005: 9). Dalam Islam, Nabi Muhammad SAW sebagai Uswah al Hasanah benar-benar menjadi kiblat dalam pelaksanaan kepemimpinan Islam. Pola kepemimpinan Rasulullah Muhammad SAW dapat dijadikan rujukan yang utama dalam kehidupan umat manusia, terutama bagi yang beriman dan bertakwa, serta selalu berdzikir kepada Allah SWT. Hal ini sejalan sebagaimana diungkap Allah dalam Surah al Ahzab (33) ayat 21 yang artinya:

"Sesungguhnya telah ada pada (diri) Rasulullah itu suri teladan yang baik bagimu

(yaitu) bagi orang yang mengharap (rahmat) Allah dan (kedatangan) hari kiamat dan

Dia banyak menyebut Allah" (Rivai, 2009: 23).

Rasulullah SAW dalam sabdanya menyatakan bahwa pemimpin suatu kelompok adalah pelayan pada kelompok tersebut, sehingga sebagai seorang pemimpin hendaklah dapat, mampu dan mau melayani, serta menolong orang lain untuk maju dengan ikhlas. Beberapa ciri penting yang menggambarkan kepemimpinan Islam adalah sebagai berikut (Rivai, 2009: 136-138): 
1. Setia, pemimpin dan orang yang dipimpin terikat kesetiaan kepada Allah.

2. Terikat pada tujuan, seorang pemimpin ketika diberi amanah sebagai pemimpin dalam melihat tujuan organisasi bukan saja berdasarkan kepentingan kelompok, tetapi juga dalam ruang lingkup tujuan Islam yang lebih luas.

3. Menjunjung tinggi syariat dan akhlak Islam, seorang pemimpjn yang baik bilamana ia merasa terikat dengan peraturan Islam, dan boleh menjadi pemimpin selama ia tidak menyimpang dari syariah.

4. Memegang teguh amanah, seorang pemimpin ketika menerima kekuasaan menganggap sebagai amanah dari Allah SWT yang disertai oleh tanggung jawab. Al Quran memerintahkan pemimpin melaksanakan tugasnya untuk Allah SWT dan selalu menunjukkan sikap baik kepada orang yang dipimpinnya.

5. Tidak sombong, menyadari bahwa diri kita ini adalah kecil, karena yang besar dan Maha Besar hanya Allah SWT, sehingga hanya Allahlah yang boleh sombong. Sehingga kerendahan hati dalam memimpin merupakan salah satu ciri kepemimpinan yang patut dikembangkan.

6. Disiplin, konsisten, dan konsekuen. Disiplin, konsisten, dan konsekuen merupakan ciri kepemimpinan dalam Islam dalam segala tindakan, perbuatan seorang pemimpin.

\section{Relasi Hasta Brata dan Islamic Leadership}

Berdasarkan pemaparan di atas, dapat ditarik benang merah bahwa Islamic leadership menghendaki adanya kepemimpinan yang islami, yang mampu menyelenggarakan organisasi dan pemerintahan dengan efektif dan benar berdasarkan tuntunan Allah melalui al Quran dan hadits Nabi Muhammad SAW. Demikian pula dengan ajaran Hasta Brata, produk asli nusantara (Jawa) yang sejatinya mengandung nilai-nilai kearifan luar biasa dalam pelaksanaan kepemimpinan. Maka patut kiranya, pemimpin di Indonesia mampu mengambil pelajaran serta mengamalkan isi yang ada di dalamnya.

Jika kita telaah lebih dalam, antara Hasta Brata dan Islamic leadership terdapat pesan yang hampir sama terkait kriteria dan ciri pemimpin ideal, dan juga pelaksanaan manajemen kepemimpinan yang baik. Keduanya menghendaki adanya pemimpin yang bijaksana, santun, adil, tegas, inspiratif, amanah, dan lain sebagainya. Berikut beberapa korelasi antara Hasta Brata dengan Islamic leadership: 
1. Laku Hambeging Kisma, pemimpin yang berbelas kasih pada siapa saja. Dalam Islam, hal tersebut dicontohkan dengan kepribadian Rasulullah saw sebagai pemimpin yang sangat berbelas kasih pada siapa saja. Nabi Muhammad SAW merasa sedih dan ikut merasakan penderitaan bila terdapat umatnya yang menderita. Hal ini sebagaimana disebutkan dalam surat al Taubah yang artinya: "Sungguh telah datang kepadamu seorang Rasul dari kaummu sendiri, berat terasa olehnya penderitaanmu, sangat menginginkan (keimanan dan keselamatan) bagimu, Amat belas kasihan lagi Penyayang terhadap orang-orang mukmin" (QS at Taubah: 128).

2. Laku Hambeging Tirta, pemimpin yang adil dan mencintai keadilan. Dalam al Quran, Allah SWT dengan tegas telah memerintahkan pada manusia sebagai pemimpin untuk berlaku adil. Sebagaimana dalam surat al Maidah yang artinya: "Hai orang-orang yang beriman hendaklah kamu Jadi orang-orang yang selalu menegakkan (kebenaran) karena Allah, menjadi saksi dengan adil. dan janganlah sekali-kali kebencianmu terhadap sesuatu kaum, mendorong kamu untuk berlaku tidak adil. Berlaku adillah, karena adil itu lebih dekat kepada takwa. dan bertakwalah kepada Allah, Sesungguhnya Allah Maha mengetahui apa yang kamu kerjakan" (QS al Maidah: 8).

3. Laku Hambeging Dahana, pemimpin yang tegas, dan bertanggung jawab. Dalam salah satu hadits, Rasulullah bersabda bahwa semua manusia adalah pemimpin, paling tidak pemimpin bagi dirinya sendiri. Dan, pada akhirnya, semua kepemimpinan akan dimintai pertanggungjawaban. Dalam sebuah hadits (Dhofir, 2005: 724) disebutkan: Ibnuu Umar ra. berkata, "Aku mendengar Rasulullah SAW. bersabda: Setiap kamu adalah pemimpin dan setiap pemimpin akan dimintai pertanggungjawaban atas yang dipimpinnya. Penguasa adalah pemimpin dan akan dimintai pertanggungjawaban atas rakyatnya. Seorang istri adalah pemimpin di rumah suaminya dan akan dimintai pertanggungjawaban atas yang dipimpinnya. Seorang pelayan adalah pemimpin terhadap harta tuannya dan akan dimintai pertanggungjawaban atas yang dipimpinnya. Dan setiap kamu adalah pemimpin dan akan dimintai pertanggungjawaban atas yang dipimpinnya."(Muttafaq 'alaih).

4. Laku Hambeging Surya, pemimpin yang memberi inspirasi, petunjuk, dan arahan. Hal tersebut telah disinggung oleh Allah dalam surat al Anbiya yang artinya: "Kami telah menjadikan mereka itu sebagai pemimpin-pemimpin yang memberi petunjuk dengan perintah Kami dan telah Kami wahyukan kepada, mereka mengerjakan kebajikan, mendirikan sembahyang, menunaikan zakat, dan hanya kepada kamilah mereka selalu menyembah" (QS al Anbiya: 73).

5. Laku Hambeging Samodra, pemimpin yang mempunyai sifat luwes, pemaaf, 
dan bijaksana seperti halnya laut yang siap menampung apa saja yang masuk ke dalamnya. Dalam sifat pemimpin Islam hal tersebut digambarkan dalam surat Ali Imran yang artinya: "Maka disebabkan rahmat dari Allah-lah kamu Berlaku lemah lembut terhadap mereka. Sekiranya kamu bersikap keras lagi berhati kasar, tentulah mereka menjauhkan diri dari sekelilingmu. karena itu maafkanlah mereka, mohonkanlah ampun bagi mereka, dan bermusyawaratlah dengan mereka dalam urusan itu. kemudian apabila kamu telah membulatkan tekad, Maka bertawakkallah kepada Allah. Sesungguhnya Allah menyukai orang-orang yang bertawakkal kepada-Nya" (QS Ali Imran: 159).

Dari ayat tersebut, ada beberapa pelajaran yang dapat kita petik berkaitan dengan masalah kepemimpinan, atau akhlak yang harus dimiliki oleh seorang pemimpin, yaitu sebagai berikut:

a) Siap untuk kecewa melihat kinerja para bawahan yang mempunyai kinerja yang tidak baik.

b) Siap untuk memaafkan bawahan yang mempunyai kinerja yang tidak baik tersebut.

c) Menjauhkan diri dari sikap atau sifat fazhzban, yaitu mempunyai lisan yang kasar dan sering menyakiti orang lain.

d) Menjauhkan diri dari sikap atau sifat ghalizhal qalb, yaitu hatinya keras, tidak mudah tersentuh dengan penderitaan orang lain.

e) Memaafkan dan memohon ampunkan mereka yang telah berbuat kesalahan atau kekeliruan (Rivai, 2009: 17).

\section{Simpulan}

Berdasar pada pembahasan yang telah dikemukakan, Indonesia sangat dimungkinkan akan kembali memperoleh kemakmuran dan kedamaian, manakala pemimpinnya bertindak adil, amanah, pemaaf, luwes, belas kasih pada rakyatnya, bijaksana, cerdas, dan jujur sebagaimana yang ada pada Islamic leadership dan Hasta Brata. Rakyat akan kembali menaruh hormat dan cinta pada pemimpin, pemimpin akan menjadi figur teladan, dan akhirnya korupsi dan penyalahgunaan wewenang jabatan akan terminimalisir. Itulah sesungguhnya model kepemimpinan yang diidam-idamkan oleh rakyat, oleh negara, dan oleh bangsa. Sejatinya dalam kepemimpinan dikenal dasar-dasar konseptual sebagai pondasi dari filosofis kepemimpinan. Dalam sejarah umat manusia di seluruh belahan dunia, masalah kepemimpinan selanjutnya berkembang dengan karakteristik dan kekhasannya masing-masing. Sebagai 
contoh adalah salah satu konsep kepemimpinan dalam perspektif Islam dan budaya nusantara Jawa.

Dalam perspektif Islam, Islamic leadership menjadi tawaran solusi dalam pelaksanaan kepemimpinan yang Islami, yaitu kepemimpinan yang bersumber pada al Quran dan hadits Nabi. Islamic leadership memberikan garis-garis besar karakteristik dan sifat-sifat pemimpin ideal. Sementara itu, dalam budaya nusantara (Jawa), juga terdapat salah satu konsep kepemimpinan yang sangat terkenal yaitu Hasta Brata. Konsep kepemimpinan Hasta Brata disimbolkan dengan delapan sifat-sifat mulia, Kisma (belas kasih), Tirta (Adil), Dahana (tegas), Samirana (teliti), Samodra (pemaaf), Surya (inspirator), Candra (penerang), dan Kartika (percaya diri). Dengan berdasar pada nilai-nilai positif dari dua konsep kepemimpinan yang telah dibahas (Islamic leadership dan Hasta Brata), pemimpin di Indonesia sepatutnya kembali mengkaji dan melaksanakan konsep kepemimpinan tersebut yang merupakan produk Islam (agama utama di Indonesia) dan budaya nusantara Jawa. Hal itu diasumsikan agar moralitas pemimpin di Indonesia sesuai dengan nilai-nilai mulia, sehingga Indonesia benar-benar akan kembali menjadi negara yang makmur, dan damai, Baldatun Thayyibatun wa Rabbun Gahafur, negeri yang Gemah Ripah Loh Jinawi Tata Tenterem Kerta Raharja, serta tercipta hubungan yang harmonis dan indah antara pemimpin dan rakyat, dan antara pimpinan dan bawahan.

\section{Daftar Pustaka}

Departemen Agama RI. 2006. Al'Aliyy Al Quran dan Terjemahnya. Bandung: CV Penerbit Diponegoro.

Dhofir, Muhil dan Dhofir, Farid. 2005. Syarah EO Terjemah Riyadhus Shalihin. Jakarta: AlI'tishom.

Habiburrahman, M. 2005. Melahirkan Pemimpin Masa Depan. Terjemahan oleh Shina'atul Qa'id. Karya Thariq Muhammad as-Suwaidan dan Faishal Umar Basyarahil. Jakarta: Gema Insani Press.

Haditsutrisno, Budiono. 2009. Islam Kejawen. Yogyakarta: Eule Book.

Lulail Yunus, Jamal. 2009. Leadership Model Konsep Dasar, Dimensi Kerja, dan Gaya Kepemimpinan. Malang: UIN-Malang Press.

Mulyono. 2009. Educational Leadership Mewujudkan Efektivitas Kepemimpinan Pendidikan. Malang: UIN-Malang Press. 
Pahlawan, R.B. Khatib. 2005. Kepemimpinan Islam Eु Dakwah. Jakarta: AMZAH.

Purwadi. 2007. Filsafat Jawa Refleksi Butir-butir Kebijaksanaan Hidup untuk Mencapai Kesempurnaan Lahir Batin. Yogyakarta: Cipta Pustaka.

Rivai, Veithzal dan Arifin, Arviyan. 2009. Islamic Leadership Membangun Superleadership Melalui Kecerdasan Spiritual. Jakarta: Bumi Aksara.

Wirjana, Bernardine R. dan Supardo, Susilo. 2002. Kepemimpinan Dasar-dasar dan Pengembangannya. Yogyakarta: ANDI 